\title{
Gonad development and reproduction of the ballyhoo half beak, Hemiramphus brasiliensis from the coastal waters of Rio Grande do Norte, Brazil
}

\author{
Oliveira, MR. ${ }^{a *}$, Silva, NB. ${ }^{b}$ Yamamoto, ME. ${ }^{a}$ and Chellappa, $S .{ }^{a, c}$ \\ apostgraduate Program in Psychobiology, Center of Bioscience, Universidade Federal do Rio Grande do Norte - UFRN, \\ Av. Salgado Filho, 3000, Lagoa Nova, CEP 59072-970, Natal, RN, Brazil \\ bDepartment of Morphology, Center of Bioscience, Universidade Federal do Rio Grande do Norte - UFRN, \\ Av. Salgado Filho, 3000, Lagoa Nova, CEP 59072-970, Natal, RN, Brazil \\ 'Department of Oceanography and Limnology, Center of Bioscience, Universidade Federal do Rio Grande do \\ Norte - UFRN, Via Costeira Senador Dinarte Medeiros Mariz, s/n, Mãe Luíza, CEP 59014-002, Natal, RN, Brazil \\ *e-mail: monicaufrn@yahoo.com.br
}

Received: July 16, 2013 - Accepted: November 8, 2013 - Distributed: May 31, 2015

(With 7 figures)

\begin{abstract}
The gonad development and reproductive aspects of Hemiramphus brasiliensis from the coastal waters of Rio Grande do Norte, Brazil were verified. This paper presents data on the length-weight relationship, sex ratio, length at first sexual maturity, gonad development, reproductive period and fecundity of $H$. brasiliensis. Females of this species predominated in the sampled population and were larger in size than the males. The length at the first sexual maturation of males was $20.8 \mathrm{~cm}$ and that of females was $21.5 \mathrm{~cm}$. The macroscopic characteristics of the gonads indicated four maturation stages. Histological studies of gonads of $H$. brasiliensis showed six phases of oocyte development and four phases of spermatocyte development. The batch fecundity of this species is $1153( \pm 258.22)$ oocytes for $50 \mathrm{~g}$ body weight of female. The microscopic characteristics of gonad development indicate that $\mathrm{H}$. brasiliensis is a multiple spawner, with active reproductive period during the months of January to June and October. The reproductive period of this species is independent of the rainy period of the region.
\end{abstract}

Keywords: sex ratio, histology of gonads, fecundity, reproductive period.

\section{Desenvolvimento das gônadas e reprodução da agulha-preta, Hemiramphus brasiliensis das águas costeiras do Rio Grande do Norte, Brasil}

\begin{abstract}
Resumo
O desenvolvimento das gônadas e os aspectos reprodutivos de Hemiramphus brasiliensis nas águas costeiras do Rio Grande do Norte, Brasil foram verificados. Este trabalho apresenta dados sobre a relação peso-comprimento, proporção sexual, comprimento de primeira maturação sexual, desenvolvimento gonadal, período reprodutivo e fecundidade de $H$. brasiliensis. As fêmeas de $H$. brasiliensis predominam na população amostrada e foram maiores em tamanho do que os machos. O comprimento da primeira maturação sexual dos machos foi de $20,8 \mathrm{~cm}$ e das fêmeas foi de $21,5 \mathrm{~cm}$. As características macroscópicas das gônadas indicam quatro estádios de maturação. Estudos histológicos de gônadas de $H$. brasiliensis mostraram seis fases de desenvolvimento do ovócito e quatro fases de desenvolvimento de espermatócitos. A fecundidade por lote desta espécie foi $1,153( \pm 258,22)$ ovócitos por $50 \mathrm{~g}$ de peso corporal da fêmea. As características microscópicas de desenvolvimento das gônadas indicam que $H$. brasiliensis apresenta desova múltipla, com um período de atividade reprodutiva nos meses de janeiro a junho e outubro. O período reprodutivo de H. brasiliensis é independente das chuvas da região.
\end{abstract}

Palavras-chave: proporção sexual, histologia das gônadas, fecundidade, período reprodutivo.

\section{Introduction}

The reproductive strategies are used by fish to maximize production and ensure the survival of offspring to adulthood. Each strategy is expressed by tactics, such as, size at first maturation, spawning period and fecundity (Potts and Wootton, 1984) which are important information for making rational measures to regulate fishing and conservation of fish stocks (King and McFarlane, 2003).

The ballyhoo half beak belong to the family Hemiramphidae, are found in shallow marine, estuarine and freshwater waters in the Atlantic, Indian and Pacific oceans (Hughes and 
Stewart, 2006). In the coastal waters of Brazil the following species have been registered: Hemiramphus brasiliensis, Hemiramphus balao, Hyporhamphus roberti, Hyporhamphus unifasciatus, Euleptorhamphus velox, Hyporhamphus coroa and Hyporhamphus salvatoris (Sampaio, 1996). Among these species, Hemiramphus brasiliensis and Hyporhamphus unifasciatus are commercially important (Lessa and Nóbrega, 2000).

Hemiramphus brasiliensis (Linnaeus, 1758) is encountered in the entire Tropical Atlantic Ocean, occurring on both sides of the Atlantic Ocean, from New England to the Southeast of Brazil, preferring calm and warm waters near the coast (Suzuki, 1983; McBride and Thurman, 2003). These fish are small in size with a maximum length of $30 \mathrm{~cm}$ (McBride et al., 1996), are important for artisanal fisheries, as bait (Berkeley et al., 1975; McBride et al., 1996) and as food (Lessa and Nobrega, 2000; Oliveira et al., 2012). Considering the economic importance of $H$. brasiliensis, the objective of this work was to verify the reproductive aspects of this species which occurs in the coastal waters of Caiçara do Norte, Rio Grande do Norte, Brazil.

\section{Material and Methods}

\subsection{Study site and sample collection}

The municipality of Caiçara do Norte outstands among the top five areas of fish production in the state Rio Grande do Norte, Brazil. In this municipality, artisanal fishing is the main economic activity, producing a wide variety of fish, such as, Hirundichthys affinis, Coryphaena hippurus, Thunnus albacares, Mycteroperca bonaci, Lutjanus synagris, L. analis, L. purpureus, L. griseus, L. jocu, Ocyurus chrysurus, Opisthonema oglinum, Mugil curema, M. liza and Hemiramphus brasiliensis (Oliveira et al., 2013).

The fish were captured on monthly basis in the coastal waters of Caiçara do Norte, northeastern Brazil, during the period of May, 2011 to April, 2012 (form 34 59' to $37^{\circ} 14^{\prime}$ longitude $\mathrm{W}$ and from $4^{\circ} 54^{\prime}$ to $6^{\circ} 34^{\prime}$ latitude S). Fish samples were captured with the help of local artisanal fishermen, who used motorboats and the ballyhoo fishing net. Samples of $H$. brasiliensis were not captured during the month of September, 2011 due to the strong winds that prevented the fishermen from going to the sea. Fish captured during the other months were numbered, weighed in total body weight (to the nearest gram, g) and measured in total body length (to the nearest centimeter, $\mathrm{cm}$ ). Each fish was dissected and sex was identified based on the macroscopic characteristics of the gonads (Mackie and Lewis, 2001). The $t$ test was utilized to check the difference between the total body length and weight of males and females.

\subsection{Length - weight relationship}

The total length and weight were determined using the absolute frequencies of males and females (mean \pm SD) of total length $(\mathrm{Lt})$ and total weight $(\mathrm{Wt})$. The length-weight relationship was determined by the equation, $\mathrm{W}=a \mathrm{~L}^{B}$, where $\mathrm{W}$ is the total weight $(\mathrm{g}), \mathrm{L}$ is the total length $(\mathrm{cm})$, $a$ is the intercept (initial rate of growth or condition factor) and $b$ is allometric coefficient (coefficient of growth or relative growth rate of fish) (Le Cren, 1951; Hayes et al., 1995; Jobling, 2002). The t-test was performed to confirm whether the value of $b$ departed significantly from the isometric value of 3 and the differences between sexes (Sokal and Rohlf, 1987).

\subsection{Sex ratio}

The sex ratio was given as males: females (M: F), calculated using the formula: total number of males/ total number of females. The chi-square $\left(\chi^{2}\right)$ was used to verify the existence of significant differences between the sex ratio of the study species and commonly expected 1:1 sex ratio (Sokal and Rohlf, 1987).

\subsection{Body size at first gonadal maturity (L50)}

Body size at first gonadal maturity $\left(\mathrm{L}_{50}\right)$ where $50 \%$ of the individuals exhibited maturing gonads was estimated from the relative frequency distribution of adult males and females, using their standard length classes (mean \pm SD) (Moreno et al., 2005).

\subsection{Macroscopic and histological descriptions of the gonads}

The location and general aspects of the gonads were observed and stage of reproductive maturity was determined using a macroscopic staging system. The features used for the macroscopic classification of gonads were based on the following external aspects: size, shape, color, presence of blood vessels, stiffness, and the space occupied in the coelomic body cavity (Murua and Saborido-Rey, 2003).

In order to avoid possible variation in the developmental stage of oocytes, due to their position in the ovaries, histological examinations were carried out on sections from the anterior (cephalic), middle (central), and posterior (caudal) regions of 20 ovaries in different developmental stages (Yoshida, 1964). These data were later compared in order to determine whether samples taken from midsection of the ovary of either lobe were representative of oocyte development.

Fragments of the ovaries and testicles were preserved in Bouin's solution for 12 to 24 hours, later embedded in paraffin, sectioned at 3-5 $\mu \mathrm{m}$ thickness, and stained with Harris Hematoxylin and Eosin (HE) and periodic acid Schiff(PAS). Gonadal developmental stages were assessed microscopically with the help of light microscope (Taimin, model TM 800), coupled with a video camera (Kodo Digital). The terminology used for staging of oogenesis followed that of Wallace and Selman (1981); West (1990), Grier and Taylor (1998) and Schulz et al. (2010).

\subsection{Fecundity}

To determine the fecundity, ovaries were removed from 14 mature females, weighed and preserved in Gilson solution for 24 hours for complete dissociation of oocytes, which were then washed and preserved in $70 \%$ ethyl alcohol. A $10 \%$ sample was removed for counting the mature oocytes, using Bogorov plates, a stereo microscope and an ocular micrometer, and the values were extrapolated to $100 \%$ (Murua and Saborido-Rey, 2003). 


\subsection{Estimation of the gonadosomatic index (GSI) and the spawning period}

The gonadosomatic index (GSI) was calculated according to Wootton et al. (1978): GSI = weight of ovary $(\mathrm{g}) /$ body weight of fish $(\mathrm{g})$ - weight of gonads $(\mathrm{g}) \times 100$. Reproductive period was determined by the temporal relative frequency distribution of the different stages of ovarian maturation (Martini and Fountain, 1981; Chellappa et al., 2010).

\subsection{Rainfall}

Rainfall data of the region was obtained from the Meteorological Department of Caiçara do Norte, Brazil, in order to verify whether rainfall influenced the reproductive season of $H$. brasiliensis. Pearson's correlation was used to correlate gonadosomatic index (GIS) with rainfall.

\section{Results and Discussion}

A total of 432 fishes were captured (160 males and 272 females). Figure $1 \mathrm{a}$ and $1 \mathrm{~b}$ shows the distribution of total length and total body weight of males and females respectively. The individuals of $H$. brasiliensis presented total length varying from 15 to $28 \mathrm{~cm}(21.26 \pm 1.89)$ and weight varying from 13.5 to $109 \mathrm{~g}(46.07 \pm 14.54)$. The total length of males during the sampling period varied from 15 to $27 \mathrm{~cm}(20.82 \pm 1.88)$, and body weight from 13.5 to $108 \mathrm{~g}(43.23 \pm 14.63)$. The total length of females varied from 15 to $28 \mathrm{~cm}(21.52 \pm 1.85)$ and body weight from 15.5 to $109 \mathrm{~g}(47.72 \pm 14.26)$. The females were bigger and heavier than the males, with significant difference in total length $(\mathrm{t}=-3.74, \mathrm{df}=431, \mathrm{p}<0.05)$ and in body weight $(\mathrm{t}=-3.10, \mathrm{df}=431, \mathrm{p}<0.05)$. H. brasiliensis captured in the coastal waters of Caiçara do Norte presented similar values of total lengths registered for the same species in Venezuela (Yelipza et al., 2011). The results indicate that females are bigger and heavier than males due to their gonads which tend to have higher mass compared to the testicles, thus agreeing with the results for the same species in South Florida (McBride and Thurman, 2003; Murua et al., 2003).

\subsection{Length - weight relationship}

Figure 2 shows the length-weight relationship of males $\mathrm{W}_{(\mathrm{g})}=0.0018 \mathrm{LT}_{(\mathrm{cm})}{ }^{3.3071}$ and females $\mathrm{W}_{(\mathrm{g})}=0.003$ $\mathrm{LT}_{(\mathrm{cm})}{ }^{3.1293}$ of $H$. brasiliensis. The allometric coefficient of males was 3.3071 and that of females was 3.1293, indicating positive allometric growth. $\mathrm{H}$. brasiliensis showed a positive correlation, with a coefficient of determination $\left(\mathrm{r}^{2}\right)$ of 0.79 for males and 0.77 for females. For the same species in Venezuela, males and females presented a minorant allometric growth, which indicates more growth in length than weight (Yelipza et al., 2011). The parameters of length-weight relationships in fish are affected by various factors, such as, the environmental conditions, the stages of gonadal maturity, sex, stomach fullness, condition factor, season, and population differences within species (Froese, 2006).
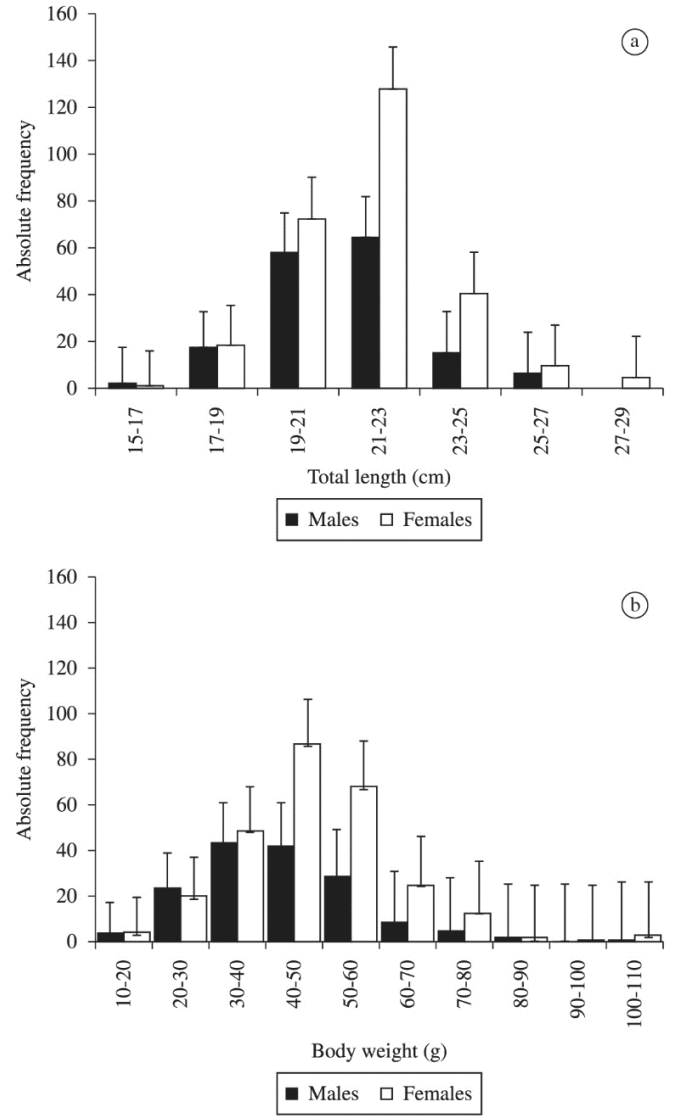

Figure 1. Mean monthly distribution according to class intervals of (a) total body length; (b) body mass of H. brasiliensis. $(\mathrm{N}$ males $=160 ; \mathrm{N}$ females $=272)$.
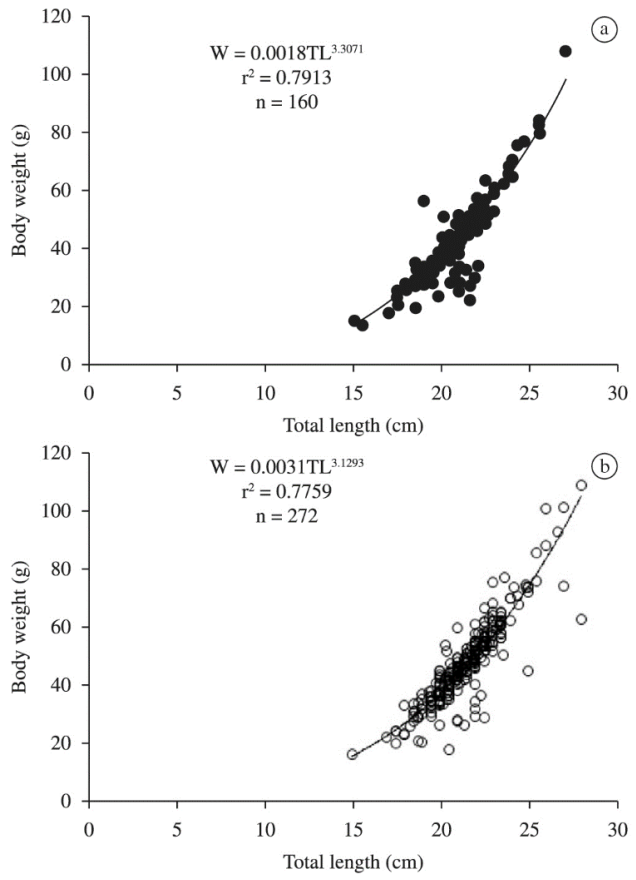

Figure 2. Length-Weight relationship of (a) males and (b) females of H. brasiliensis. 


\subsection{Sex ratio}

In this study the sex ratio of $H$. brasiliensis $(1: 1,7)$ differed significantly $\left(\chi^{2}=29.03 ; \mathrm{p}<0.05\right)$ from the expected ratio (1:1), with a predominance of females in the sampled population. The distribution of the monthly frequency of occurrence of males and females shows significant difference in the sex ratio of $H$. brasiliensis. In the months of October, November, January and March there was a predominance of females (Figure 3 ). The sex ratio could be affected by various factors related to fishery, season of the year, shoals in the feeding and spawning areas (Sarojini, 1957; Silva and Silva, 1981; Lasiak, 1982). Spawning habitats of female ballyhoo $H$. brasiliensis and balao (H. balao $)$ in south Florida were described by McBrige and Thurman (2003). In the present study $H$. brasiliensis habits the coastal waters and reproduces in the same locality, which confirms the observation of McBride and Thurman (2003).

Information on sex ratio is important for understanding the relationship between individuals, the environment and the state of the population (Vicentini and Araújo, 2003). The sex ratio may vary from the expected 1:1 from species to species, or even in the same population at different times, being influenced by several factors such as adaptation of the population, reproductive behavior, food availability and environmental conditions (Nikolsky, 1963; Emlen and Oring, 1977; Baroiller and D'Cotta, 2001; Brykov et al., 2008; Vandeputte et al., 2012).

\subsection{Length at first sexual maturity (L50)}

The total length at first sexual maturity was $20.8 \mathrm{~cm}$ for males and $21.5 \mathrm{~cm}$ for females (Figure 4). The males of $H$. brasiliensis attained first gonadal maturity at smaller body lengths than females $(t=3.62, d f=408, p<0.05)$. Length at maturity could be directly affected by changes in the quantity of energy reserves available for gonadal development (Morgan, 2004), indirectly affected by the changes in growth, which influence the onset of gonadal maturation (Engelhard and Heino, 2004). The males of $H$. brasiliensis in the present study matured earlier than the females, since they require lesser quantity of energy reserves for gonad maturation. The females of $H$. brasiliensis in the coastal waters of South Florida attained maturity at $19.8 \mathrm{~cm}$ and males were not included in this study (McBride and Thurman, 2003).

\subsection{Macroscopic and histological descriptions of the gonads}

The ovaries and testes were paired bi-lobed structures, symmetrical, elongated and joint in the posterior part to form a short duct leading to the urogenital pore. They were located in the posterior-dorsal part of the coelomic cavity, ventral to the kidneys and swim bladder. The immature testes were small and translucent. Maturing testes were more developed and were whitish in color. The mature testes were white and spent testes were flaccid and brown in color with hemorrhagic appearance. During maturation, the ovaries were pinkish to light orange in

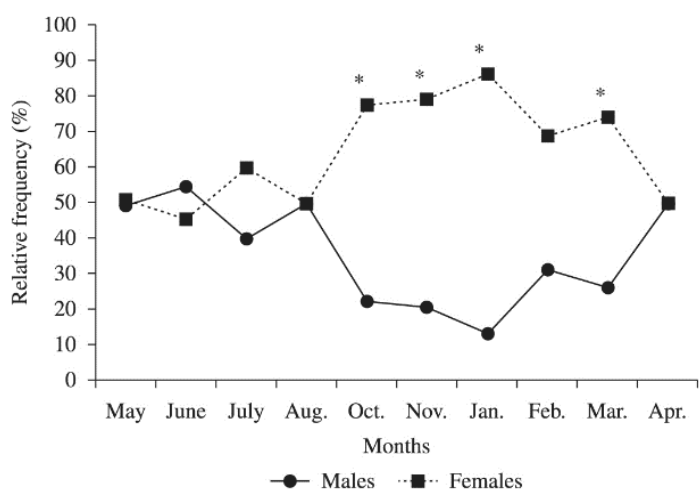

Figure 3. Monthly sex ratio of $H$. brasiliensis. * Significant difference of the observed sex ratio from the expected 1:1. $(\mathrm{N}$ males $=160 ; \mathrm{N}$ females $=272)$.

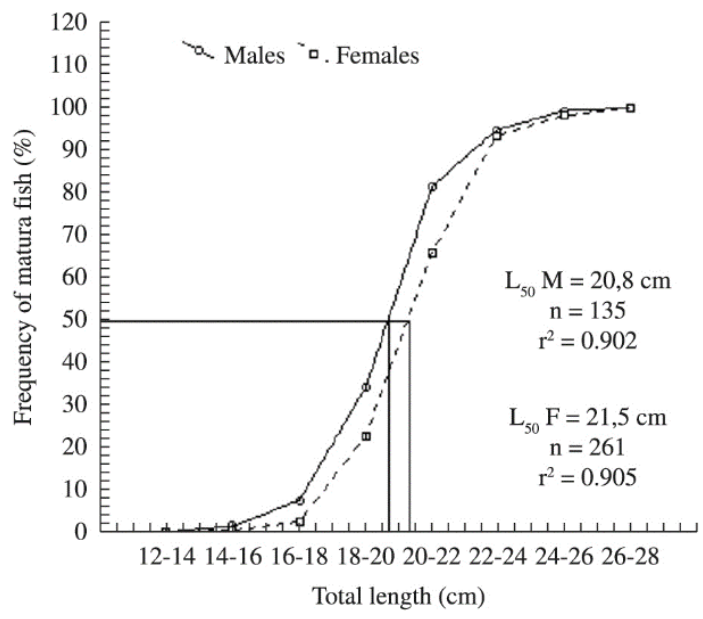

Figure 4. The cummulative percentage of observed mature fish in relation to body size for males and females of the H. brasiliensis. The inserted lines represent the estimated size range where $50 \%$ of the fish were mature.

color and developed progressively by increasing in size and vascularization. The mature ovaries were turgid and occupied $2 / 3$ of the coelomic cavity. The mature ovaries were turgid with numerous big oocytes visible to the naked eye, and the partially spent ovaries were flaccid. These results are similar to those registered for three fish species of the family Hemiramphidae in the coastal waters of Australia (Hughes and Stewart, 2006).

The microscopic observations of the ovaries of $H$. brasiliensis showed six different phases of oocyte development, constituted in two stages (Figure 5). The first or the pre vitellogenic stage included the young germinative cell phase of the reserve stock. The second or vitellogenic stage included the beginning of lipid deposition (Phase II), lipid vitellogenic phase (Phase III), lipid and protein vitellogenic phase (Phase IV), complete vitellogenesis phase (Phase V) and hydrated oocyte phase (Phase VI). Post-ovulatory follicles were also observed. 
Phase II: Initially the nucleus was in the center, with one or two nucleoli (intensely basophilic) with a well defined cytoplasm. The nucleoli became more in number and were present in the periphery of the nucleus. Phase III (beginning of lipid deposition): This stage was characterized by small yolk vesicles in the cytoplasm. Phase IV (lipid vitellogenic phase): The oocytes showed the central nucleus, cytoplasm was less basophilic than in the previous phase, and with vacuoles representing the lipid deposition. Phase $\mathrm{V}$ (lipid and protein vitellogenic phase): Besides the lipid droplets, the oocytes showed the deposition of protein in the form of platelets in the cytoplasm. Phase VI (complete vitellogenesis phase): In this stage the lipidic droplets were not observed and the protein granules were bigger in size. The basophilic color of the cytoplasm disappeared totally and the nucleus migrated. Hydrated oocytes were highly modified, the cytoplasm was hydrated, which resulted in the adhesion of the yolk granules. Post-ovulatory follicles: the follicular cells were condensed, entering the space which was occupied earlier by the oocytes, thus constituting, a body formed by cellular chords, folded in all directions.

The oocyte development observed in the present work is in accordance with that registered in Florida, other than the post-ovulatory follicles, which showed partial spawning (McBride and Thurman, 2003).

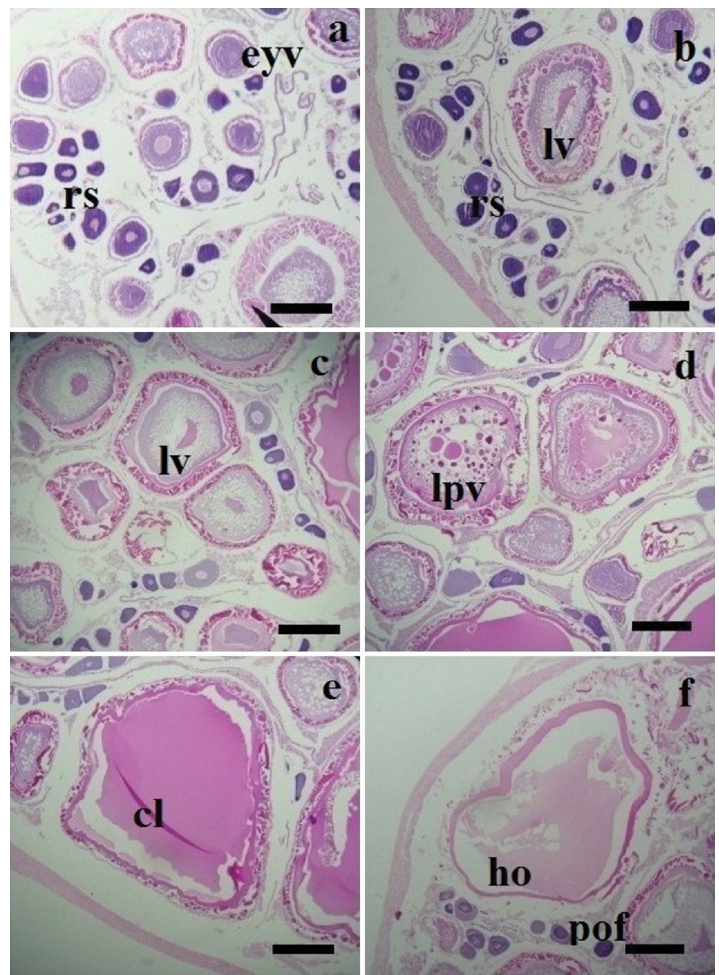

Figure 5. Histological aspects of oocyte development stages of $H$. brasiliensis: (a) perinucleolus stage or reserve stock (rs) and early yolk vesicle (eyv); (b) lipid vitellogenesis (lv) and rs; (c) lv (d) lipid and protein vitellogenesis (lpv); (e) oocytes with complete vitellogenesis (cl); (f) oocytes in hydration (ho) and post-ovulatory follicle (pof) (scale bar $=50 \mu \mathrm{m})$.
Histological analyses indicated four developmental phases of the spermatogonia in $H$. brasiliensis: spermatogonia, spermatocytes, spermatids and spermatozoa (Figure 6).

\subsection{Fecundity}

The microscopic characteristics of gonad development of $H$. brasiliensis showed multiple spawning. The batch fecundity of $H$. brasiliensis varied from 862 to 1354 , with an average of $1153( \pm 258.22)$ vitellogenic oocytes for $50 \mathrm{~g}$ body weight of female. For the same species in the coastal waters of South of Florida, the fecundity was 1164 oocytes for $100 \mathrm{~g}$ body weight of female (McBride and Thurman, 2003). Fecundity is a specific reproductive tactic (Murua and Saborido-Rey, 2003) and is adapted to the life cycle conditions of the species (Witthames et al., 1995), varying with growth, population density, body size, food availability and mortality rate (Murua et al., 2003).

\subsection{GSI, reproductive period and rainfall}

The mean monthly values of GSI of females in relation to the rainfall variation of the study area are shown in Figure 7 . The mean monthly values of GSI varied from 1.47 to 4.10 . Frequency of monthly gonadal maturation stages of females indicates that mature individuals occur throughout the year. However, there were peaks of GSI during the months of June, October, January and April. Variations of GSI and the frequency of monthly gonadal maturation stages show that $H$. brasiliensis has an active reproductive period during the months of January to June and again in October. The period of January, April and June when females of $H$. brasiliensis were ready to reproduce, coincided with the rainy period of the region, showing a positive correlation $(r=0.7)$. However, the females were also mature during October when there were no rains. As such, the breeding period of this species is independent of the rainy period. For the same species it was observed that the breeding occurs in the month of April with peaks during the end of spring and the beginning of summer in Florida (McBride and Thurman, 2003).

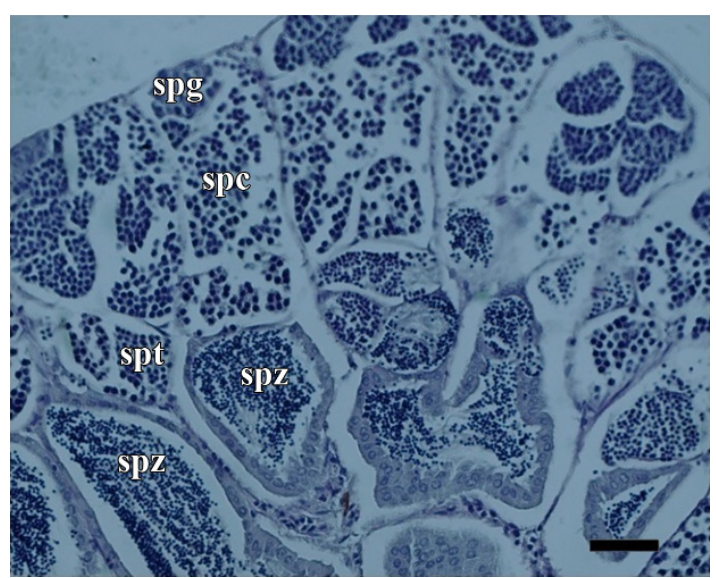

Figure 6. Histological aspects of spermatocyte developmental stages of $H$. brasiliensis: spermatocyte (spc), spermatid (spt); spermatozoon $(\mathrm{spz})($ scale bar $=50 \mu \mathrm{m})$. 


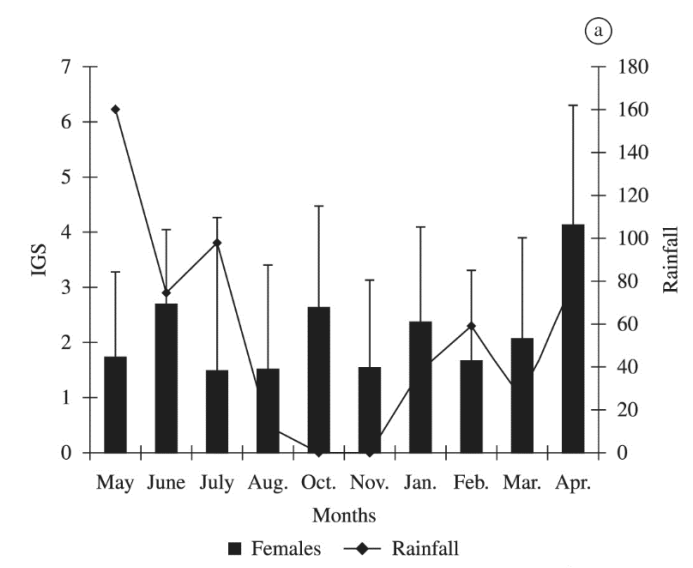

(b)

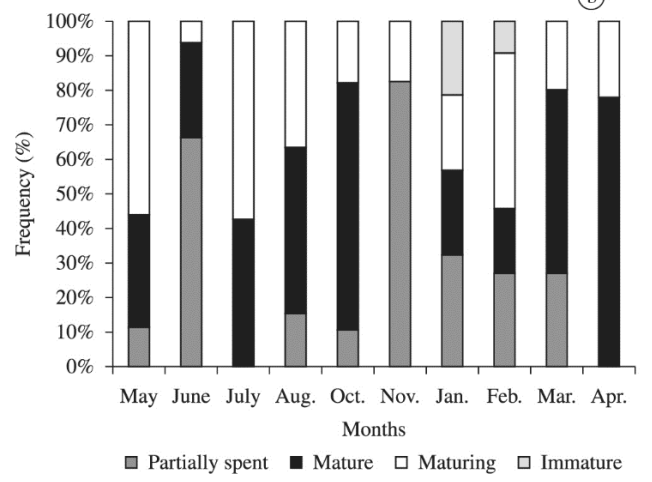

Figure 7. Temporal distribution of GSI $( \pm \mathrm{SE})$ (histograms) of $H$. brasiliensis females in relation to rainfall (lines) (a) and monthly frequency of maturity stages of the females of the H. brasiliensis (b) ( $\mathrm{N}$ females $=272)$.

This study indicates that females predominate in the sampled population of $H$. brasiliensis. The females were larger in size than the males, which attained sexual maturity earlier than the females. The macroscopic gonadal stages coupled with histological analysis reflect the spawning activities of $H$. brasiliensis adequately. Information on the reproductive aspects, such as, the length-weight relationship, sex ratio, length at first sexual maturity, gonad development, and fecundity of $H$. brasiliensis is important for making rational measures to regulate its fishing and conservation.

\section{References}

BAROILLER, JF. and D'COTTA, H., 2001. Environment and sex determination in farmed fish. Comparative biochemistry and physiology. Toxicology \& pharmacology : CBP, vol. 130, no. 4, p. 399-409. http://dx.doi.org/10.1016/S1532-0456(01)00267-8. PMid:11738628

BERKELEY, SA., HOUDE, ED., WILLIAMS, F. and University of Miami, 1975. Fishery and biology of ballyhoo on the southeast Florida coast. Coral Gables: University Miami Sea Grant Program. p. 1-15. Sea Grant Special Report, no. 4.

BRYKOV, VA., KUKHLEVSKIĬ, AD., SHEVLIAKOV, EA., KINAS, NM. and ZAVARINA, LO., 2008. Sex ratio control in pink salmon (Oncorhynchus gorbuscha) and chum salmon
(O. keta) populations: the possible causes and mechanisms of changes in the sex ratio. Genetika, vol. 44, no. 7, p. 906-912. PMid: 18767538

CHELLAPPA, S., LIMA, JTAX., ARAÚJO, A. and CHELLAPPA, NT., 2010. Ovarian development and spawning of Serra Spanish mackerel in coastal waters of Northeastern Brazil. Brazilian Journal of Biology $=$ Revista Brasileira de Biologia, vol. 70, no. 2, p. 451-456. http://dx.doi.org/10.1590/S1519-69842010005000012. PMid:20379657

EMLEN, ST. and ORING, LW., 1977. Ecology, sexual selection, and the evolution of mating systems. Science, vol. 197, no. 4300, p. 215-223. http://dx.doi.org/10.1126/science.327542. PMid:327542

ENGELHARD, GH. and HEINO, M., 2004. Maturity changes in Norwegian spring-spawning herring before, during, and after a major population collapse. Fisheries Research, vol. 66, no. 2-3, p. 299-310. http://dx.doi.org/10.1016/S0165-7836(03)00195-4.

FROESE, R., 2006. Cube law, condition factor and weight-length relationship: history, meta-analysis and recommendations. Journal of Applied Ichthyology, vol. 22, no. 4, p. 241-253. http://dx.doi. org/10.1111/j.1439-0426.2006.00805.x.

GRIER, HJ. and TAYLOR, RG., 1998. Testicular maturation and regression in the common snook. Journal of Fish Biology, vol. 53, no. 3, p. 521-542. http://dx.doi.org/10.1111/j.1095-8649.1998. tb00999.x.

HAYES, DB., BRODZIAK, JKT. and O'GORMAN, JB., 1995. Efficiency and bias of estimators and sampling designs for determining length-weight relationships of fish. Canadian Journal of Fisheries and Aquatic Sciences, vol. 52, no. 1, p. 84-92. http:// dx.doi.org/10.1139/f95-008.

HUGHES, JM. and STEWART, J., 2006. Reproductive biology of three commercially important Hemiramphid species in southeastern Australia. Environmental Biology of Fishes, vol. 75, no. 2, p. 237-256. http://dx.doi.org/10.1007/s10641-006-0023-3.

JOBLING, M., 2002. Environmental factors and rates of development and growth. In HART, PJ. and REYNOLDS, JD. (Eds.). Fish Biology. Oxford: Blackwell Publishing. p. 97-122. Handbook of fish biology and fisheries, vol. 1.

KING, JR. and MCFARLANE, GA., 2003. Marine fish life history strategies: applications to fishery management. Fisheries Management and Ecology, vol. 10, no. 4, p. 249-264. http://dx.doi. org/10.1046/j.1365-2400.2003.00359.x.

LASIAK, A., 1982. Aspects of the reproductive biology of the Southern mullet Liza richardsoni from Algoa Bay, South Africa. South African Journal of Zoology, vol. 18, no. 2, p. 89-95.

LE CREN, ED., 1951. The length-weight relationship and seasonal cycle in gonadal weight and condition in the perch (Perca fluviatilis). Journal of Animal Ecology, vol. 20, no. 2, p. 201-219. http://dx.doi.org/10.2307/1540.

LESSA, RP. and NÓBREGA, MF., 2000. Guia de identificação de peixes marinhos da região nordeste. Recife: Programa REVIZEE / SCORE-NE. 127 p.

MACKIE, MC. and LEWIS, PD., 2001. Assessment of gonad staging systems and other methods used in the study of the reproductive biology of the narrow-barred Spanish mackerel, Scomberomorus commerson, in Western Australia. Fisheries Research Report, vol. 136, p. 1-32.

MARTINI, EE. and FOUNTAIN, RK., 1981. Ovarian cycling frequency and batch fecundity in the queenfIsh, Seriphus politus: 
attributes representative of serial spawning fishes. Fishery Bulletin, vol. 79 , no. 3 , p. $547-560$.

MCBRIDE, RS. and THURMAN, PE., 2003. Reproductive biology of Hemiramphus brasiliensis and H. balao (hemiramphidae): maturation, spawning frequency, and fecundity. The Biological Bulletin, vol. 204, no. 1, p. 57-67. http://dx.doi.org/10.2307/1543496. PMid:12588745

MCBRIDE, RS., FOUSHEE, L. and MAHMOUDI, B., 1996. Florida's halfbeak, Hemiramphus spp., bait fishery. Marine Fisheries Review, vol. 58, p. 29-38.

MORENO, T., CASTRO, JJ. and SOCORRO, J., 2005. Reproductive biology of the sand smelt Atherina presbyter Cuvier, 1829 (Pisces:Atherinidae) in the central-east Atlantic. Fisheries Research, vol. 72, no. 1, p. 121-131. http://dx.doi.org/10.1016/j. fishres.2004.06.016

MORGAN, MJ., 2004. The relationship between fish condition and the probability of being mature in American plaice (Hippoglossoides platessoides). ICES Journal of Marine Science, vol. 61, no. 1, p. 64-70. http://dx.doi.org/10.1016/j.icesjms.2003.09.001.

MURUA, H. and SABORIDO-REY, F., 2003. Female reproductive strategies of marine fish species of the North Atlantic. Journal of Northwest Atlantic Fishery Science, vol. 33, p. 23-31. http:// dx.doi.org/10.2960/J.v33.a2.

MURUA, H., KRAUS, G., SABORIDO-REY, F., WITTHAMES, PR., THORSEN, A. and JUNQUERA, S., 2003. Procedures to estimate fecundity of marine fish species in relation to their reproductive strategy. Journal of Northwest Atlantic Fishery Science, vol. 33, p. 33-54. http://dx.doi.org/10.2960/J.v33.a3.

NIKOLSKY,GV., 1963. The ecology of fishes. London: Academic Press. $352 \mathrm{p}$

OLIVEIRA, IMB., OLIVEIRA, MR., YAMAMOTO, ME. and CHELLAPPA, S., 2012. Biologia reprodutiva de agulha-preta, Hemiramphus brasiliensis (Linnaeus, 1758) (Osteichthyes: Hemiramphidae) das águas costeiras do Rio Grande do Norte, Brasil. Biota Amazônia, vol. 2, no. 2, p. 44-53.

OLIVEIRA, MR., CARVALHO, MM., SOUZA, AL., MOLINA, WF., YAMAMOTO, ME. and CHELLAPPA, S., 2013. Caracterização da produção do peixe-voador, Hirundichthys affinis em Caiçara do Norte, Rio Grande do Norte, Brasil: durante 1993 a 2010. Biota Amazônia, vol. 3, no. 2, p. 23-32.

POTTS, GW. and WOOTTON, RJ., 1984. Fish reproduction. London: Academic Press.

SAMPAIO, JR., 1996. Índice dos Peixes Marinhos Brasileiros. Fortaleza: Gráfica Editora VT. 124 p.

SAROJINI, KK., 1957. Biology and fisheries of the grey mullets of Bengal. 1. Biology of Mugu parsia Hamilton with notes on its fishery in Bengal. Indian Journal of Fisheries, vol. 4, no. 1, p. $160-207$.
SCHULZ, RW., FRANÇA, LR., LAREYRE, JJ., LE GAC, F., CHIARINI-GARCIA, H., NOBREGA, RH. and MIURA, T., 2010. Spermatogenesis in fish. General and Comparative Endocrinology, vol. 165, no. 3, p. 390-411. http://dx.doi. org/10.1016/j.ygcen.2009.02.013. PMid:19348807

SILVA, EIL. and SILVA, SS., 1981. Aspects of the biology of grey mullet, Mugil cephalus L., adult populations of a coastal lagoon in Sri Lanka. Journal of Fish Biology, vol. 19, no. 1, p. 1-10. http://dx.doi.org/10.1111/j.1095-8649.1981.tb05806.x.

SOKAL, RR. and ROHLF, FJ., 1987. Introduction to biostatistics. 2nd ed. New York: Freeman. 363 p.

SUZUKI, CR., 1983. Guia dos peixes do Litoral brasileiro. Rio de Janeiro: Book’s Edições. 394 p.

VANDEPUTTE, M., QUILLET, E. and CHATAIN, B., 2012. Are sex ratios in wild European sea bass (Dicentrarchus labrax) populations biased? Aquatic Living Resources, vol. 25, no. 1, p. 77-81. http://dx.doi.org/10.1051/alr/2012002.

VICENTINI, RN. and ARAÚJO, FG., 2003. Sex ratio and size structure of Micropogonias furnieri (Desmarest, 1823) (Perciformes, Sciaenidae) in Sepetiba Bay, Rio de Janeiro, Brazil. Brazilian Journal of Biology = Revista Brasileira de Biologia, vol. 63, no. 4, p. 559-566. http://dx.doi.org/10.1590/S1519-69842003000400003. PMid:15029367

WALLACE, RA. and SELMAN, K., 1981. Cellular and dynamic aspects of oocyte growth in teleosts. American Zoologist, vol. 21, p. $325-343$

WEST, G., 1990. Methods of assessing ovarian development in fishes: a Review. Australian Journal of Marine and Freshwater Research, vol. 41, no. 2, p. 199-222. http://dx.doi.org/10.1071/ MF9900199.

WITTHAMES, PR., GREER WALKER, M., DINIS, MT. and WHITING, CL., 1995. The geographical variation in the potential annual fecundity od dover sole, Solea solea, from European shelf waters during 1991. Netherlands Journal of Sea Research, vol. 34, no. 1-3, p. 45-58. http://dx.doi.org/10.1016/0077-7579(95)90013-6.

WOOTTON, RJ., EVANS, GW. and MILLS, L., 1978. Annual cycle in female three-spined sticklebacks (Gasterosteus aculeatus L.) from an upland and lowland population. Journal of Fish Biology, vol. 12, no. 4, p. 331-343. http://dx.doi.org/10.1111/j.1095-8649.1978. tb04178.x.

YELIPZA, LR., ACOSTA, V., PARRA, B. and LISTA, M., 2011. Aspectos biométricos de Hemirhamphus brasiliensis (Peces:Hemirhamphidae), Isla de Cubagua, Venezuela. Zootecnia Tropical, vol. 29, no. 4, p. 385-398.

YOSHIDA, HO., 1964. Skipjack tuna spawning in the Marquesas Islands and Tuamotu Archipelago. Fish Bulletin, vol. 65, p. 479-488. 